\title{
Crossing the Genre Divide: Women and Ethics in the Detective Novels of Dorothy L. Sayers
}

\section{Suzie Remilien ${ }^{1}$}

Dorothy L. Sayers used the Harriet Vane character to explore themes that are more characteristic of the mainstream novel than the detective fiction of the Golden Age. Focus is on the four Lord Peter Wimsey novels featuring Harriet Vane that address the role of women in society, and intellectual integrity, to outline Sayers' shift from detective fiction to the mainstream novel. [Article copies available for a fee from The Transformative Studies Institute. E-mail address: journal@transformativestudies.org Website: http://www.transformativestudies.org (C2010 by The Transformative Studies Institute. All rights reserved.]

KEYWORDS: Detective Fiction, Dorothy L. Sayers, Harriet Vane, The Novel.

\section{INTRODUCTION}

The non-detective elements in Dorothy L. Sayers' Lord Peter Wimsey books have attracted much critical attention. These non-detective elements, chiefly the amateur sleuth's romantic relationship with detective novelist Harriet Vane, were viewed as an impediment to the crimesolving function of the detective. Jacques Barzun and other critics of the 1930s lamented this kind of intrusion into what they saw as an inflexible genre. Although these purists could not appreciate these additions, critics such as Margaret Hannay were more receptive to the later books featuring Vane. Hannay argues that Vane was instrumental in helping to de-

\footnotetext{
${ }^{1}$ Suzie Remilien is an Assistant Professor and Reference and Instruction Librarian at Long Island University in Brooklyn, New York. Her research interests include 20thcentury British detective fiction, popular fiction and gender and genre studies. Address correspondence to: Library, Long Island University, Brooklyn, NY 11201; e-mail: srem75@yahoo.com.
} 